\title{
Commentaries
}

\section{Neoliberalism and the Pandemic}

\author{
Alfredo Saad-Filho \\ Department of International Development, King's College London, \\ London, UK \\ alfredo.saad-filho@kcl.ac.uk
}

\begin{abstract}
This paper offers a political economy interpretation of the CoviD-19 pandemic, framed around its relationship to the dynamics, contradictions and limitations of global neoliberalism. It argues that the pandemic emerged in a context of growing inequalities and deepening crises in neoliberal economies and their political systems, and that the pandemic is likely to reinforce the exclusionary tendencies in the current phase of capitalism, with detrimental implications for democracy. In turn, the pandemic has revealed the limitations of neoliberalism like never before, with adverse consequences for the legitimacy of capitalism itself, and opening unprecedented spaces for left political activity.
\end{abstract}

\section{Keywords}

COVID-19 - pandemic - neoliberalism - crisis - democracy 


\section{Crises in Neoliberalism}

The COVID-19 pandemic is the worst global public health emergency since the 'Spanish' flu that enveloped the world after World War I: a catastrophe following a nightmare. In comparison with the flu's 5 o million victims in a world with a population under 2 billion, the number of deaths directly and indirectly due to CoviD-19 remains small; nevertheless, the pandemic has produced countless tragedies, traumatised survivors and triggered the sharpest economic contraction in the history of capitalism.

The pandemic hit a world already suffering from growing economic imbalances, worsening finance-driven crises, political turmoil and the corrosive impact of the 'Great Stagnation' that followed the global financial crisis (GFC), which started in 2007. In addition, global neoliberalism has become increasingly reliant on overt coercion and violence since the GFC, leading to an escalating crisis of democracy and the rise of authoritarian forms of government. In recent times, these governments have tended to be led by 'spectacular' leaders, often supported by mass movements combining modern forms of personality cult with more or less close relationships with traditional far-right currents and groups. Brazil, India, Hungary, Turkey and the USA under Donald Trump offer clear examples of these processes.

These political and policy developments have been closely related to the erosion of the non-market protections introduced in previous years and phases of capitalism (most obviously during the so-called Welfare State), and the deployment of 'fiscal austerity' backed up by punishing measures against the poor, the underprivileged, the neglected and those who are hard to reach, serve and provide for; attacks against any form of collective representation; repression against most expressions of dissent, ranging from lynching-by-media to victimisation, interception of communications and persecution by the police, the security services or the military, as well as the emergence of a myriad of groups overtly attached to fascism or even Nazism. At the same time, and to some extent paradoxically, post-GFC neoliberalism has led to new forms of attachment to state economic intervention even in strongly neoliberal Western economies, often centred around state provision of expensive infrastructure. Distinct from that of its predecessors, this presumably 'public' form of provision invariably takes the form of (heavily financialised) support for private enterprise at public expense, and with socialised risk. Even to talk about 'state provision', however incorrectly, has changed the policy atmosphere, especially in the USA and the UK. However, this is far from a symbol of revitalisation of, and much less a return to, Keynesianism; this is, instead, part of a desperate 
attempt to create demand and skilled jobs, fuel economic growth after many years of stagnation and strengthen the Western economies in order to contain the rise of China. So far, this approach has not been either significant enough or transformative enough to mark a shift away from neoliberalism, or even to herald new forms of global economic competition. It remains to be seen if it will change after COVID-19, especially through the so-called Biden plan in the USA.

\section{Roots of the Crises}

The processes outlined above are rooted in multiple factors, including the cracks in the ideological hegemony of neoliberalism since the G FC. The notion of 'free markets' has been undermined by the growing realisation that neoliberalism has sharply negative distributional and other consequences and that it creates undesirable patterns of employment and social reproduction, with implications for social welfare and much more. The GFC highlighted these adverse implications, as it revealed the costs and consequences of perpetuating a parasitic system of accumulation that veers endlessly between stagnation and destabilising speculative bubbles while, in the meantime, producing a mode of life that is widely considered to be undesirable from the point of view of the majority of people, and unsustainable in view of the imperative of protecting the known forms of life on Earth.

The longer-term picture was similarly concerning. The economic restructuring taking place under neoliberalism was perceived to have created large cohorts of economic 'losers': new technologies, financialisation and the 'globalisation' of production led to the elimination of entire professions and large numbers of careers, many of them until then stable and relatively well paid; they were often replaced by unskilled, precarious and badly paid jobs, lacking dignity, stability, pensions, benefits, promotions prospects and much else. These profound transformations in economic life had adverse implications for tens of millions of people, most dramatically in the advanced capitalist economies. The legitimate concerns that emerged from them could not be articulated clearly and, by and large, demonstrations of dissatisfaction by the 'osers' were ignored if not ridiculed by the institutions of the state, established politicians and the mainstream media. Their attitude was facilitated by the destruction of the left in previous stages of neoliberalism: left-wing political parties, trade unions, social movements, community organisations and other forms of political mobilisation and social life were, invariably, the first victims of attack in the transitions to neoliberalism. 
The throttling of traditional forms of expression of dissatisfaction fed political alienation and fostered a political vacuum in which opposition tended to be dissolved into anomie, absorbed into the far right, or enraptured by 'spectacular' authoritarian neoliberal leaders promising to resolve the problems that the 'losers' were unable to confront. The rise to prominence of authoritarian leaders, often peddling nonsensical interpretations of neoliberalism and its consequences, pushing absurd claims to competence, and advancing facile policy options depending upon their own (self-proclaimed) 'strength of character', was facilitated by a bizarre process of individualisation of the truth under neoliberalism: the cult of 'consumer choice', self-improvement, and the erosion of respect for expertise - which lost purchase as economists, financiers and other 'experts' denied the experiences of the losers despite the widespread perception of dysfunctionalities and perversities in the world of neoliberalism - fed a growing disregard for science, evidence and established truths. Previously marginal, extreme or ridiculous views found fertile terrain in the echo chambers of social media, and drove shallow but increasingly radical accounts of neoliberalism and its consequences (with 'flat Earth', QAnon, antivax and related conspiracy theories becoming especially prominent recently). These cults merged into the idolatry of authoritarian neoliberal political leaders peddling comforting claims and whose every trespass would be forgiven because they seemed 'genuine' and magically 'in touch' with the concerns of large masses of people.

It follows that the political crisis of democracy and the drift towards an increasingly authoritarian form of neoliberalism cannot be reduced to epiphenomenal events or electoral blunders that will be corrected when voters eventually realise that self-centred, thieving and megalomaniac politicians rejecting neoliberal 'expertise' will invariably fail, and that their projects ought to be replaced by a (temporarily lost) 'third wayist' normality. This will not happen, despite the wishes of the punditry and the whimpers of middle-of-theroad politicians. Instead, the rise of authoritarian modes of governance stems from the economic and social damages inflicted by neoliberalism, followed by the fracture of its ideological legitimacy and the consolidation of a repressive politics of crisis management after the GFC. This form of politics centres on the manipulation of sectional (exclusionary) resentments in order to shore up the system of accumulation by means of permanent strife, escalating repression, high rates of exploitation within and between countries, and the plunder of the resources of the poor, poorer countries and nature. The underlying social divisions have been contained, channelled and deflected by nationalism, racism and violence, often encased within right-wing, authoritarian and populist political forms. 


\section{Enter the Pandemic}

The degenerating economic, social and political dynamics outlined above was overwhelmed by the CoviD-19 pandemic. The spread of the pandemic triggered the deepest and sharpest economic collapse in the history of capitalism, which tended to hit especially severely the advanced economies that had been most weakened by several decades of 'policy reform' under neoliberalism. This economic shock could be contained only by unprecedented levels of public sector intervention aiming to support production, demand and employment, compensate the contractionary impact of the inevitable lockdowns, and settle the health and other costs of the pandemic. Those desperate interventions will have long-term consequences for the functioning of capitalism. In particular, in addition to disarticulating the global processes of extraction and circulation of surplus value, the pandemic also had profound implications for social reproduction and daily life. They range from unprecedented forms of state intervention to secure the basic economic relations of capitalism, protect public health and maintain order, to changes in urban spaces because of the decline of the high streets, the rise of online shopping and the transformations of the service sector more generally, with much else in between.

At the global level, countries, states and provinces confronted the pandemic in sharply distinct ways, with strikingly dissimilar outcomes. A heterogeneous group was highly successful in largely eliminating the coronavirus, among them China, Cuba, Ghana, Kerala State in India, New Zealand, Senegal, Singapore, Taiwan and Vietnam. Others witnessed extraordinary policy failures culminating in tens of thousands of avoidable deaths, for example, Brazil, Ecuador, Hungary, India, Italy, Sweden, Turkey, the UK and the USA.

In very general terms, the most uncompromisingly neoliberal economies were incapable of mounting coherent policy responses to the pandemic. Instead, theirgovernments tended to attach themselves to (more or less explicit) policies of 'herd immunity', an approach replete with social Darwinistic overtones. These states also tended to have been more heavily restructured by the neoliberal 'reforms' - that is, they tended to be institutionally disarticulated, heavily privatised and colonised by piratical syndicates committed to plunder rather than management. It is unsurprising that these governments have found it difficult to gauge the threat, reach decisions in the interests of the majority, mobilise state capacities in the interests of public health or implement co-ordinated policies to address the pandemic. In contrast, in places where neoliberal ideology was less influential and the 'reforms' of the state, industry and health provision were less advanced, notions of common citizenship tended to be more prominent, welfare states were stronger and health 
systems were generally more comprehensive and resilient. Those states also tended to have more policy space to deploy better co-ordinated policies. They often could suppress the coronavirus and resume 'normal' life faster and with much lower casualties; however, the failures elsewhere forced the 'successful' states to keep themselves isolated from the world in order to avoid importing new cases of COVID-19.

\section{Policy Lessons}

The experiences of policy success and failure addressing the pandemic suggest six significant lessons.

First, neoliberal states can be highly efficient in protecting the profits and the interests of the privileged, and they have learned the art of rescuing finance from its self-inflicted disasters. However, these states have great difficulty in performing other functions of governance, especially protecting the population from the ravages of misfortune and securing jobs, incomes and basic services for the vast majority. The pandemic shows that this must be done not only for reasons of justice and distributive economic policy; this is also important for effective health policies, since security of employment and income will make the population healthier and, in the event of a pandemic, they will allow more people to stay at home, easing the load on the health system and accelerating the economic recovery. Costs should be no obstacle: since the authorities have been able to provide hundreds of billions to banks, hedge funds and large corporations time and again, they can certainly support the vulnerable and fund a resilient and universal health system, if there is the political will to do so.

Second, the more that neoliberal ideologues and policy-makers reconstructed the state along neoliberal lines, and the more they enforced the marketisation of social reproduction, the lower was the capacity of these states to mobilise resources and expertise to respond to emergencies. This limitation was strikingly obvious in what may be called the 'Quartet of Calamity' (USA, UK, Brazil and India).

Third, there is no trade-off between health and the economy. That is, the claim that countries must choose a position along a purported continuum between lockdown (ensuring minimal loss of life in the short term but carrying heavy economic costs) and 'herd immunity' (with the opposite balance of costs and benefits) is a misleading guide to public policy. What has been proven, instead, is that the economy cannot function if the population is either insecure or unhealthy. Experience also shows that the countries that resisted 
lockdowns and flirted with 'herd immunity' tended to suffer the largest human disasters as well as the deepest economic collapses. These outcomes reinforce the significance of integrated public policy, state capacity and a strong manufacturing base, in contrast with the systematic depredation of the economy and the public sector under neoliberalism.

Fourth, it was possible to eliminate the coronavirus in many different ways. In particular, the supposed trade-off between democracy and effective combat against the virus was false, because countries have performed more or less well depending on their state capacity and public policies, rather than their political regimes. Since it was possible to combat the pandemic successfully in a democratic framework (e.g. Australia, Denmark, Finland, Iceland and New Zealand), the widespread escalation of authoritarianism in the wake of COVID-19 was a travesty: the primary goal of surveillance, tracking, repression and the politics of command was not the implementation of appropriate health policies. Instead, the goals were to disguise policy failures in the short term and validate social control in the longer term. In contrast, the experiences of success did not depend primarily on repression, but on distinct combinations of state capacity, purposeful, centralised and co-ordinated action, economic resources, technology, testing, tracing, capillarity of health systems and social control. These are the features of successful industrial policy, applied to the field of public health. In contrast, the 'failed' states tended to be disorganised, disarticulated and to have been more radically restructured by the neoliberal 'reforms', as well as having deindustrialised drastically, fragmented their own supply chains in the name of 'globalisation', embedded 'competition' into their health systems, acted late and unwillingly against COVID-19, failed to test or trace the virus, imposed lockdowns late and reluctantly, and lacked PPE, ICU beds and ventilators. This is, then, a pandemic with neoliberal characteristics, in which the impositions of neoliberalism were directly responsible for hundreds of thousands of deaths.

Fifth, the pandemic revealed starkly how the neoliberal cult of competition and individual maximisation had fed nationalism and racism, debased science and interacted closely with the individualisation of the truth. This is especially corrosive, because if truth is open to 'choice' there will be no possibility of dialogue between people with different viewpoints - this is the collapse of the possibility of democracy, because of a surfeit of neoliberal individualism.

Sixth, the economic burden of covid-19 will be much higher than that of the GFC. Most governments, especially in the advanced Western economies, spent huge sums during the pandemic, in addition to lowering interest rates whenever this was possible (given the exceptionally low rates already prevailing for a decade). Many governments expressed their intention to cover those 
costs by shifting to a 'new fiscal austerity' as soon as possible, but this would be untenable. Fiscal austerity is unjustifiable in economic terms, and it will be widely seen as illegitimate given the boost to wealth due to government support to the asset markets. It is also impossible for the poor and the remaining public services to bear the burden of another round of 'adjustment'. Austerity policies could be imposed only by force, and these policies, their regressive implications and the repression that must accompany them will undermine the legitimacy of the state and damage the mass base of any government. These limitations suggest the likelihood of a long period of crisis politics with unpredictable implications.

\section{Conclusion}

From the point of view of the left, the strains of the pandemic have shown that the economy is a social system characterised by strong interdependencies ('we are the economy'), that we are bound together as humans and that the universal provision of basic services is far more efficient than privatised, forprofit and fragmented supply. It follows that it is incumbent upon the state to secure access to universal basic services, jobs and incomes, opening the way to the transformation of dysfunctional (but highly profitable) essential sectors into public utilities. This can give a decisive contribution to the democratisation and definancialisation of the economy and the transformation of the crises in neoliberalism into a crisis of neoliberalism. It has also been shown that responses to the current economic, political and health crises in neoliberalism (not to speak of the crises in the environment, water, food production and so on, which also have neoliberal features) must be based on internationalist values, since only global solutions can be effective in an integrated world: we truly are 'in it together'. This approach can pave the way for a politics of humanity and hope, organised around the defining concerns of the left with equality, collectivity and economic and political democracy, against (a, by now, clearly zombie form of) neoliberalism. Our future hangs in the balance, and only left activity can secure a life worth living. 